\title{
甶丸腫瘍78例の治療成績
}

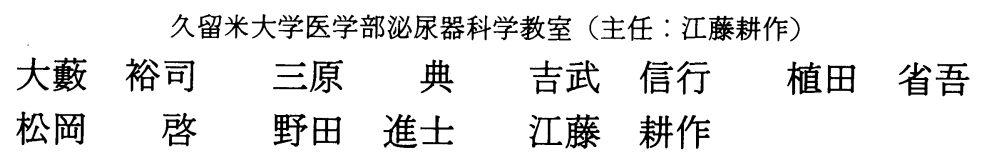

\section{TREATMENT OF SEVENTY-EIGHT PATIENTS WITH TESTICULAR TUMORS}

\author{
Yuji Oyabu, Tsukasa Mihara, Nobuyuki Yoshitake, Shogo Ueda, Kei Matsuoka, \\ Sinshi Noda and Kosaku Eto \\ Department of Urology, Kurume University School of Medicine
}

(Director: K. Eto)

Seventy-eight patients with testicular tumors were treated in our clinic between April, 1972 and October, 1990.

The average age of patients with seminoma ( $37.5 \mathrm{yrs})$ was higher than that ( $24.5 \mathrm{yrs})$ of those with non-seminomatous germ cell tumor (NSGCT). Histopathologically, 34 patients had seminoma and 36 patients had NSGCT. The remaining 8 patients had non-germinal cell tumors.

The 5-year survival rate was $76.7 \%, 90.3 \%$ and $75.8 \%$ for all patients, seminoma group and NSGCT group, respectively. As for seminoma group, the 5-year survival rate was $100 \%, 50.0 \%$ and $33.3 \%$ for Stage I, Stage IIb and Stage III, respectively. The survival rate of Stage IIb and Stage III in seminoma group were lower than Stage I statistically. In NSGCT group, the 5-year survival rate was $100 \%$ for Stage I and $26.7 \%$ for Stage III, between the two groups there was significant difference.

The higher serum LDH and HCG levels, the lower the survival rate in NSGCT. Serum AFP, $\beta$-HCG levels and ESR were unrelated to the survival rate.

The survival rate for the patients treated by the chemotherapy including CDDP was compared to those treated by the other therapy in germ cell tumor ( $\geqq$ Stage IIb). The survival rate of CDDP group was higher than the others $(\mathrm{p}<0.01)$.

Key words: testicular tumors, clinical study, survival rate

\begin{abstract}
要旨：今回我々は，久留米大学医学部泌尿器科学教室で，1972年 4 月以降1990年10月までに経験した鼻 丸腫湯78例の臨床的検討を行った。年齢ではセミノーマが平均37.5歳, non seminomatous germ cell tumor (以下 NSGCT) は平均24.5歳で，七ミノーマが高かった $(\mathrm{p}<0.01)$. 病理組織学分類では，七ミ ノーマが34例 (43.6\%) と最も多く, 奇形癌16例 (20.5\%), 奇形腫 6 例 (7.7\%) の順であった. 全症

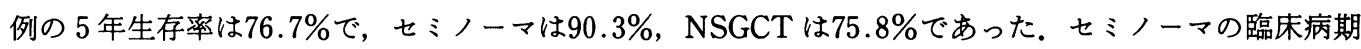
別生存率では，Stage I は Stage IIb 及びIIIに比べ，生存率がよく( $\mathrm{p}<0.001)$ ，また NSGCT でも Stage I は Stage III に対し生存率が良かった $(\mathrm{p}<0.001)$ 。予後に与える背景因子に関し，主訴発現より初診ま での期間, 術前の血清 AFP 值, 血清 LDH 值, 血清 HCG 值, 血清 $\beta$-HCG 值と血沈を検討した. この うち統計的有意差を認めたのは NSGCT における血清 LDH 值と血清 HCG 值であった. CDDPを含む 化学療法の生存率に与える影響についての検討では, CDDP 群の方が生存率が良かった $(\mathrm{p}<0.01)$. キーワード：辠丸腫瘍, 臨床的研究, 生存率
\end{abstract}

\section{緒言}

辠丸腫瘍は，比較的発生頻度は低いが，幼小児およ び青壮年者に好発する悪性腫瘍としては重要な疾患の $1 つ て ゙ あ る 。$ 進行性辠丸腫瘍は有効な化学療法のな
かった1970年代前半までは, 極めて予後の悪い腫瘍と されてきた。しかし，1970年代半ばからは，腫場マー カーの確立による再燃や再発の早期発見, CT の普及 に伴う画像診断の進歩による正確な病期診断や治療効 
果の判定が可能となった。ささらに, 1970年後半よりの 急速な化学療法の発達, とりわけ CisDiamminedichloroplatinum (以下 CDDP) の出現以 来, PVB 療法1)や VAB 療法2)31などの CDDP そべース とした化学療法の出現により, 従来極めて予後不良と されてきた進行性辠丸腫瘍も, “完全治癒しらる癌”と なりつつあるとされている4).

今回我々は, 久留米大学医学部泌尿器科学教室で, 1972年 4 月以降 1990 年 10 月までに経験した辠丸腫瘍 78 例を集計し, 治療および予後を中心に臨床的統計事項 について検討した。

\section{対象・方法}

1972年 4 月以降1990年10月 1 日までに久留米大学医 学部泌尿器科学教室において経験した78例を対象とし た。このらち胚細胞腫瘍 (以下 GCT) は70例で, 主に これを中心に追跡調査し, 予後を判定した。病期分類 および組織分類は泌尿器科・病理辠丸腫瘍取扱い規 約5)に準じた。なお，臨床病期分類は胸部 X 線撮影，排 泄性腎孟造影, リンパ管造影, また1970年代後半ょり は超音波断層法および腹部 CT scan, 最近では MRI などの結果を加兄, 殬丸腫瘍取扱い規約5)の日本泌尿 器科学会病期分類に従って判定した.

治療方法はセミノーマの Stage Iに対しては, 主に 高位除辠術と逆 $\mathrm{Y}$ 字型照射野で, 総量 $30 \sim 50 \mathrm{~Gy}$ (平均 $35.8 \mathrm{~Gy}$ )の放射線照射を行った。 また, 術前後の腫瘍 マーカーが上昇していた症例に対しては化学療法を追 加した場合もあった。

Stage IIb 以上の進行セミノーマに対しては, 高位除 殬術と放射線治療に加光, 化学療法を追加したもの 1 例, 後腹膜リンパ節郭清術（以下 RPLND）を追加し たものが 1 例あった。また, これら治療に加兄, 肺転 移巣を外科的切除した症例も 1 例経験した。

NSGCT の Stage I に対しては, 高位除䁄術のみが 7 例で, このらちの 5 例は奇形腫であった。しかし, 11例には, 高位除辠術後に化学療法を追加し, このう ちさらに 2 例は放射線治療を, 1 例は後腹膜リンパ節 転移を起こして来たので, RPLNDを行った. NSGCT の Stage IIb 以上の進行癌に対しては, 治療拒否をし た Stage IIIb の䄉毛癌 1 例と, 放射線治療と RPLND を行った奇形癌 1 例を除く14/16例 (87.5\%) に化学療 法を行った。さらに化学療法に追加して, このうちの 4 例には放射線治療を，4 例にはRPLNDを， 2 例に はRPLND および肺転移巣の切除を行った。

化学療法は1970年代後半 CDDP が出現する前は,
Actinomycin D P Cyclophosphamide や Vincristine などの化学療法剂を用いた多剂併用療法を行ってき た.CDDP 出現以降は PVB療法1)および VAB-6療法6) を行っている.さらに Stage IIb 以上の症例で, CDDP を含む寛解導入化学療法と RPLNDによる初期治療 で CR を得られなかった症例に対し，VP-16を使用し た Salvage 療法を行った ${ }^{7)}$.

生存率はKaplan-Meier 法による累積生存率を用 い, 各群間の統計学的有意差は generalized Wilcoxon testによって判定した。予後算出の起点は除殬術日と し，1990年10月 1 日現在の成績をまとめた。生存率に 与える因子として検討したのは組織型, 臨床病期分類, 主訴発現より初診までの期間, 術前の血清 AFP 值, 血 清 $\mathrm{LDH}$ 值, 血清 HCG 值, 血清 $\beta$-HCG 值, 血沈 $60^{\prime}$ 値 の 8 項目である. 主訴発現より初診までの期間は 3 カ 月末満の群と 3 カ月以上の群に分けた。術前の血清 $\mathrm{AFP}$ 值は0～20,21２00,201～ng/ml の 3 群に分け, 血清 $\mathrm{LDH}$ 值は, $0 \sim 400,401 \sim 800,801 \sim \mathrm{IU} / l$ の 3 群 に分け，血清 HCG 值は， $0 \sim 100,101 \sim \mathrm{mIU} / l$ の 2 群に分け, 血清 $\beta$ - HCG 値は, $0 \sim 1.0$ と $1.1 \sim \mathrm{ng} / \mathrm{ml}$ の 2 群に分け，血沈60值は $0 \sim 20,21 \sim \mathrm{mm}$ の 2 群に分 け，生存率の差を検討した。

次に化学療法のうち CDDP を含む化学療法の効果 をみる目的で, Stage IIb 以上の症例について, CDDP を含む化学療法を行った群と行わなかった群について 予後を検討した。

\section{結 果}

自験例78例の辠丸腫瘍を睪丸腫瘍取扱い規約 従って病理組織学的に分類すると, 表 1 のように, 七 ミノーマが34例 (43.6\%), non-seminomatous germ cell tumor (以下 NSGCT) が36例 (46.2\%), その他 の腫場が 8 例 (10.2\%) であった. NSGCT の内訳は, 単一組織型では, 胎児性癌 5 例 $(6.4 \%)$, 卵黄囊腫 2 例 (2.6\%), 䋐毛癌 3 例 (3.8\%), 奇形腫 6 例 (7.7\%) であり, 複合組織型では奇形癌16例(20.5\%), 䄉毛上 皮癌十奇形癌 2 例 (2.6\%), 䋐毛上皮癌十胎児性癌 1 例 (1.3\%), 奇形癌十七ミノーマ 1 例 (1.3\%) であっ た。

臨床病期と組織型の関係をみると,全体では Stage I が53例 (67.9\%), Stage II が 9 例(11.6\%), Stage III が16例 (20.6\%) であった。 セミノーマでは Stage I が 28例 (82.4\%), Stage II が 3 例 (8.8\%), Stage III が 3 例 (8.8\%) であり，一方 NSGCT は Stage I が19例 (52.3\%), Stage II が 6 例 (16.7\%), Stage III が11 
表 1 組織学的分類

\begin{tabular}{|c|c|c|}
\hline \multicolumn{3}{|c|}{ I 胚細胞由来 } \\
\hline \multicolumn{3}{|c|}{$\mathrm{A}$ 単一細胞型 } \\
\hline & セミノーマ & 34 \\
\hline & 胎児性癌 & 5 \\
\hline & 卵黄囊腫 & 2 \\
\hline & 䄉毛癌 & 3 \\
\hline & 奇形腫 & 6 \\
\hline \multicolumn{3}{|c|}{ B複合組織型 } \\
\hline & 胎児性癌＋奇形腫 & 16 \\
\hline & 䄉毛癌十その他 & 3 \\
\hline & その他の組合せ & 1 \\
\hline \multicolumn{3}{|c|}{ II その他 } \\
\hline & Malignant lymphoma & 5 \\
\hline & 類表皮哀胞 & 1 \\
\hline & 腺腫様腫瘍 & 1 \\
\hline & 横紋筋肉腫 & 1 \\
\hline
\end{tabular}

表 2 組織型と病期分類

\begin{tabular}{l|c|c|c|c}
\hline & セノーマ & NSGCT & その他 & 合 計 \\
\hline Stage I & 28 & 19 & 6 & 53 \\
Stage IIa & 1 & 1 & 0 & 2 \\
Stage IIb & 2 & 5 & 0 & 7 \\
Stage IIIa & 1 & 0 & 1 & 2 \\
Stage IIIb & 2 & 11 & 1 & 14 \\
\hline
\end{tabular}

NSGCT : Non seminomatous germ cell tumor

表 3 組織型と年齢分布

\begin{tabular}{c|c|c|c|c}
\hline 年齢 & セミノーマ & NSGCT & その他 & 合計 \\
\hline $0 \sim 9$ & 0 & 8 & 2 & 10 \\
$10 \sim 19$ & 1 & 3 & 2 & 6 \\
$20 \sim 29$ & 11 & 11 & 0 & 22 \\
$30 \sim 39$ & 7 & 10 & 0 & 17 \\
$40 \sim 49$ & 10 & 2 & 0 & 12 \\
$50 \sim 59$ & 3 & 1 & 1 & 5 \\
$60 \sim 69$ & 1 & 1 & 2 & 4 \\
$70 \sim$ & 1 & 0 & 1 & 2 \\
\hline
\end{tabular}

NSGCT : Non seminomatous germ cell tumor

例（30.6\%）であった（表 2).

年龄分布は 9 カ月から 75 歳 (平均 31.5 歳) で, その らちセミノーマは18歳から75歳 (平均 37.5 歳), NSGCT は 9 カ月から62歳 (平均24.5歳) であった。 セミノーマはNSGCT に比べ有意に年齢が高い傾向 を示し $(\mathrm{p}<0.01)$, 七ミノーマは20 49歳に多く, NSGCT は $0 〜 9$ 歳と 20〜30歳に二峰性のピークを認 めた（表 3 ).

患側は, 右42例 (53.9\%), 左33例 (42.3\%) で, 両

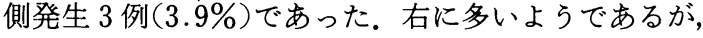
統計的有意差はなかった。 セミノーマでは右19例 (55.9\%)，左13例 (38.2\%)，両側 2 例 (5.9\%) であっ た。次にNSGCT では右19例 $(52.8 \%)$, 左17例 （47.2\%）であった。

また，両側発生のうち 1 例は，始めは片側のみの睪 丸腫大に気付き， 3 カ月後に反対側の異常に気付いた 異時発生例である. 初診時, 既に Stage IIIb でもあり, 両側ともに原発巣なのか，一側が他側からの転移なの かが問題になるが，これを臨床的に確定することは困 難であり，統計上は両側発生とし，集計した。また， 両側発生例の病理組織はセミノーマ 2 例, Malignant lymphoma 1 例であった。

主訴としては，無痛性鼻丸腫大が72/78例（92.3\%） で多かったが，有痛性醉丸腫大を認めたものも6/78例 （7.7\%）にみられた。 また䁄丸腫大以外の症状として は腰痛 $4 / 78$ 例 $(5.1 \%)$, 呼吸器症状を $2 / 78$ 例 (2.6\%) を認めた。

また初発症状から初診までの期間は 2 日より 5 年と 幅があるが，平均 6.8 月であった。 5 年で初診した 1 例以外は 3 年以内に受診していたが，このうち 1 年以 内の受診が57例 $(82.6 \%)$ を占めていた。

次に，確認しえた範囲では，停留粹丸に腫瘍を認め たものは $4 / 61$ 例 $(6.2 \%)$ であり, 冝丸外傷の既往があっ たものも $3 / 68$ 例 (4.4\%) に認められた。な拉，停留辠 丸に発生したものは 4 例すべてがセミノーマであり， 患側は右 2 例，左 2 例であった．臭丸の外傷の既往を もつ 3 例に関しては，明らかな腫瘍発生との因果関係 を証明できたものはなかった。

除辠術後の観察期間は，1990年10月 1 日の時点で， 最短 1 カ月から最長 21 年, 平均 5 年 7 カ月であった. 図 1 亿全症例の Kaplan-Meier 法による累積生存率を 示すが, 1 年生存率は $88.9 \%, 3$ 年生存率は $81.0 \%$, 5 年生存率は $76.7 \%$ で10年生存率は $74.1 \%$ であった。 次にセミノーマ, NSGCT, および両者を含めた Germ cell tumor (以下 GCT) の生存率曲線を図 2 に示すが, 1 年生存率はそれぞれ，90.3\%，93.7\%，90.8\%で， 3 年生存率は $90.3 \%, 75.8 \%, 83.8 \%$ で， 5 年生存率 は90.3\%，75.8\%，81.5\%であった。セミノーマ， NSGCT, GCT 間の生存率には統計学的有意差は無 かった。 セミノーマの臨床病期分類別の生存率曲線(図 3 ）では，観察期間中 Stage I は全例生存していた. Stage IIaは 1 例のみで，これを除く Stage I, Stage IIb, Stage III の 5 年生存率はそれぞれ, 100\%, 
図 1 辠丸腫瘍78例全症例の累積生存率

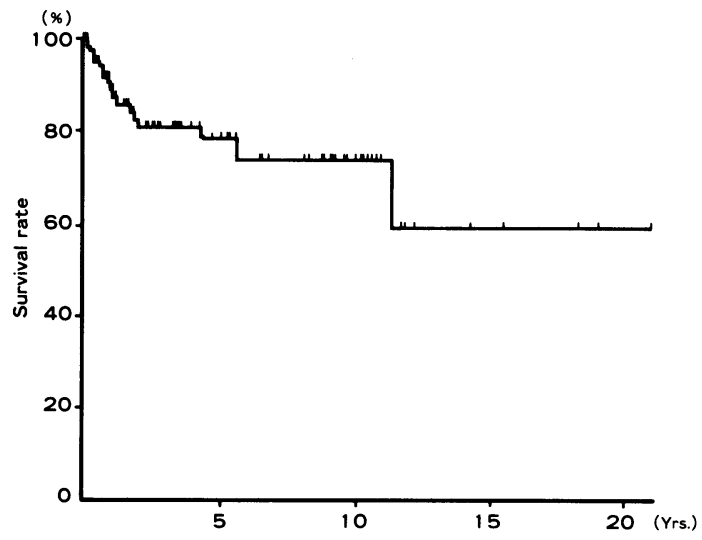

図 2 セミノーマ, NSGCT, GCT 別累積生存率

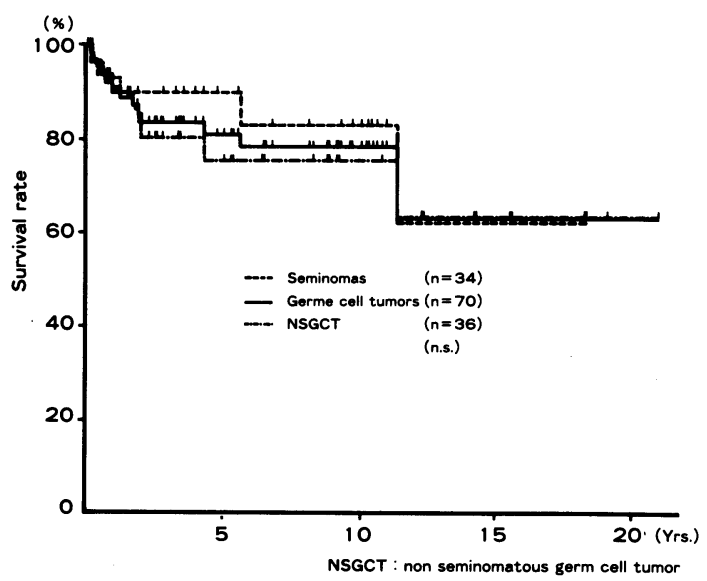

$50.0 \%, 33.3 \%$ あった. Stage I の生存率は Stage IIb, Stage III に対し危険率0.1\%で有意に良好であっ た. また, NSGCT の臨床病期分類別の生存率曲線(図) 4 )でも, Stage I は観察期間中全例生存しており， 1 例しかなかった Stage IIa を除く, Stage I, Stage IIb, Stage III の 5 年生存率はそれぞれ，100\%，80.0\%， 15.0\%であった. Stage IはStage III に対し危険率 $0.1 \%$ で有意差を認めた。

また主訴発現より初診までの期間が 3 カ月未満の群 と 3 カ月以上の群の，5年生存率はそれぞれ $88.7 \%$, $76.8 \%$ であり, 統計学的有意差は認められなかった。

次にNSGCTに打ける術前の腫瘍マーカーによる 生存率の差をみた。血清 AFP 值の 0 〜 20群, 21 200 群，201 ng/ml 群の， 5 年生存率はそれぞれ $100 \%$, $60.0 \%, 85.7 \%$ であり，統計的有意差はなかった。血
図 3 セミノーマにおける臨床病期別累積生存率

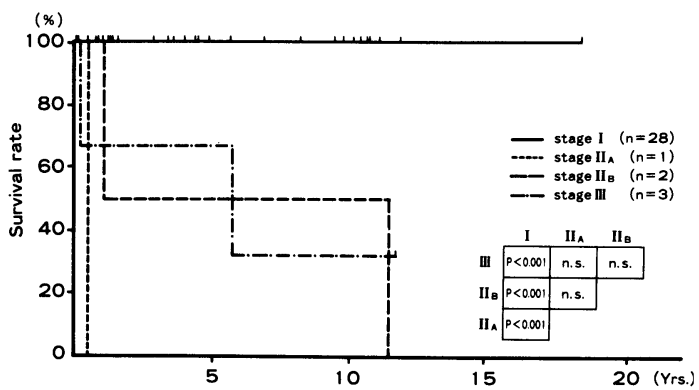

図 4 NSGCT における臨床病期別累積生存率

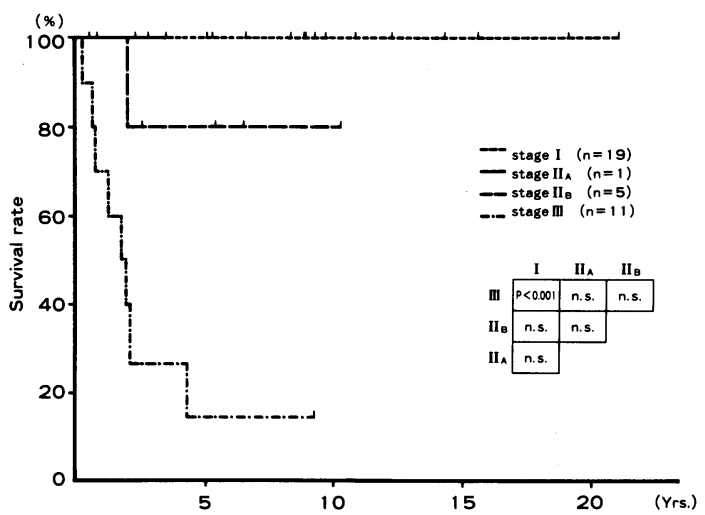

図 5 NSGCT における術前血清 LDH 値別累積生存 率

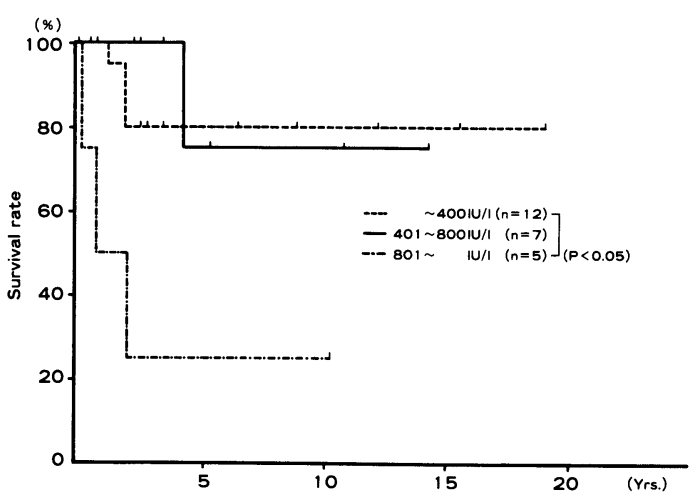

清 $\mathrm{LDH}$ 值, $0 \sim 400$ 群, $401 \sim 800$ 群, $801 \sim \mathrm{IU} / l$ 群の, 5 年生存率はそれぞれ $80.0 \%, 85.0 \%, 25.0 \%$ あり， 血清 LDH 値正常群は血清 LDH 値801〜群に比べ危 険率 $5 \%$ で有意に生存率が良かった（図 5 ）。血清 HCG 值に関しても, 生存率をみると, 0 〜 100群と $101 \sim \mathrm{mIU} / l$ 群の 5 年生存率は $100 \%$ と $25.0 \%$ であり, 危険率 $5 \%$ で血清 HCG 値正常群は異常群より生存率 
因 6 NSGCT における術前血清 HCG 值別累積生存

率

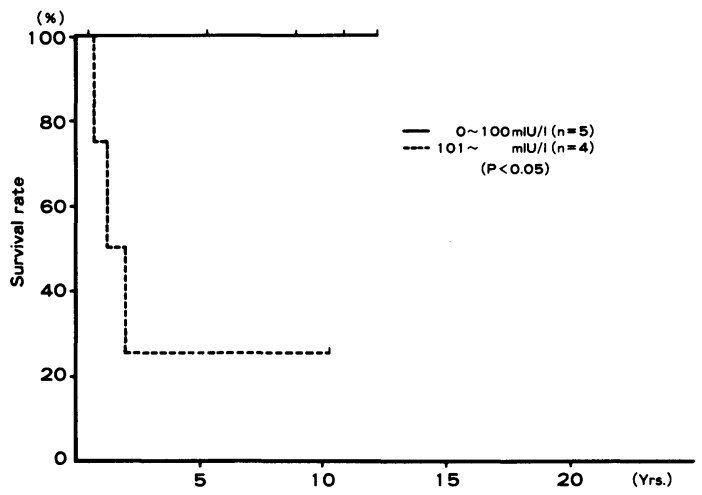

が良かった(図 6 ). 一方，血清 $\beta$-HCG 值では $0 \sim 1.0$ と $1.1 \sim \mathrm{ng} / \mathrm{ml}$ の 2 群の 5 年生存率は $88.9 \%$ と $75.0 \%$ であり, $\beta$-HCG 正常群の方が高い生存率を示したが, 全期間での検討では統計学的有意差は認めなかった。 血沈 $60^{\prime}$ 値で $0 \sim 20,21 \sim \mathrm{mm}$ の 2 群の 5 年生存率はそ れぞれ $82.2 \% ， 67.3 \%$ で, 各期間では血沈異常群の予 後が悪い傾向を示すものの，全期間では統計学的有意 差は認めなかった。

また，七ミノーマについても，以上の術前の血清 AFP 值, 血清 LDH 值, 血清 HCG 值, 血清 $\beta$-HCG 値 と血沈 $60^{\prime}$ 値の 5 項目に関して, 生存率に対する影響を 検討したが，いずれも統計的有意差は認めなかった。

次に化学療法のうち CDDP を含む化学療法の効果 の検討では，セミノーマに関しては，CDDPを含む化 学療法群の 5 年生存率は $50.0 \%$ に対し, それ以外の群 は $0 \%$ であった。 また NSGCT では, CDDP 群の 5 年 生存率は $48.0 \%$ でそれ以外の群は $20.0 \%$ （31力月打ち 切り）であった，GCT での CDDP 群の 5 年生存率は $57.1 \%$ で，それ以外の群は $12.5 \%$ (31力月打ち切り) であった（図 7 )。このうち，GCT では危険率 $1 \%$ で 有意の統計学的差を認めた。 セミノーマと NSGCT そ れぞれも，各期間毎の生存率は，CDDP を含む化学療 法群の方が高かったが，症例数が少なく，全期間を通 しての統計学的検討では有意差は認められなかった。

なお，CDDPを含む化学療法を行った群と行わな かった群の年齢はそれぞれ $26.2 \pm 7.9$ 歳と $34.7 \pm 12.1$ 歳で, 統計的有意差はなかった。 また, 組織学的分類 では CDDP 群がセミノーマ2 例, NSGCT 11例, 非 CDDP 群ではセミノーマ 3 例, 非セミノーマ5 例で あった。 また, 臨床病期は CDDP 群が Stage IIb 4 例,
図 $7 \quad$ Stage IIb 以上の進行癌における CDDPを含む 化学療法群とそれ以外の群の累積生存率

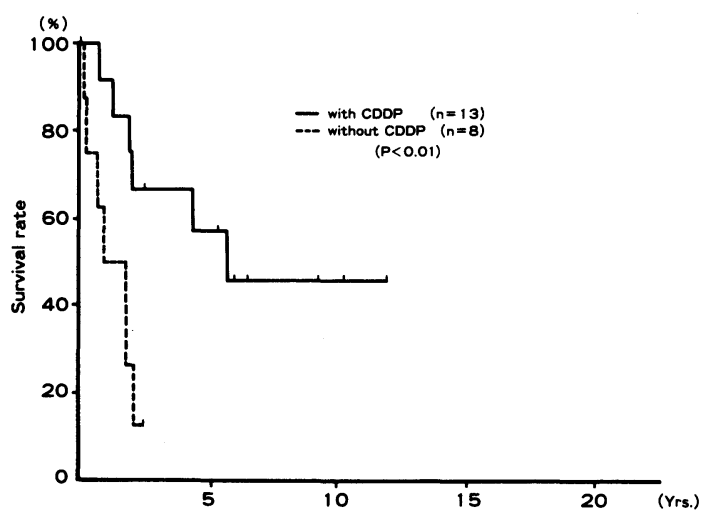

Stage III 9 例で, 非 CDDP 群は Stage IIb 3 例, Stage III 5 例とこれも統計的有意差は見られない.CDDP 群 に扣ける初期化学療法は PVB 療法 8 例, VAB-6療法 5 例で，非 CDDP 群は Actinomycin D や Cyclophpsphamide や Vincristine などの化学療法剤を用いた多 剂併用療法を 4 例に行った。CDDP 群と非 CDDP 群の 背景因子の差に明らかなものは無かった。

\section{考 寒}

本邦における鼻丸腫瘍の頻度は人口 10 万人に対し $0.7 \sim 1.1 \%^{8)}$ とされ，外来患者に対する割合も 0.12 0.32\% ${ }^{9)}$ とされる比較的稀な疾患である.

年齢分布では, 従来の報告9)10) と同様に, 七ミノーマ は比較的高龄者に多く, NSGCT は若年者に多く認め られた。また，主訴に関しては有痛性睪丸腫大は7.7\% と, 驚塚 ${ }^{11)}$ や高橋ら ${ }^{10)}$ の報告に比べても少ない。

患側では右側が $53.9 \%$ とやや多いようであるが統計 的有意差はない，諸家の報告9でも一般に右側が多い とする場合すあるが, 差はないようである。また, 我々 の集計では両側発生例を 3 例 (3.9\%) に認めた。入澤 $ら^{12)}$ の本邦136例の両側辠丸腫場の集計でも, 辠丸腫瘍 の3.6\%に認められるとされ，さらに同時発生 42 例に対 し，異時発生85例と異時発生の方が多いとしている.

また，外傷の既往を 3 例 (4.4\%) に認めたが，外傷 と殬丸腫瘍の発生に関連を示唆させる, 受傷より腫瘍 発生までの期間や組織型の特異性などは我々の症例で も認めず，外傷により患者の注意が睾丸に向けられた とも考えられ，一般にも因果関係は不明とされてい る $^{13)}$.

停留辠丸も 4 例 (6.2\%) に認めた。菊池ら ${ }^{14)}$ による 本邦報告の停留辠丸に発生した辠丸腫瘍179例の集計 
では, 右側に多く, 腹部停留辠丸がやや多く, 組織学 的にはセミノーマが約 $62 \%$ と最も多いとされている。

自験例も全例がセミノーマであった。

生存率に関しては, 当教室全症例に関しての 5 年生 存率は $76.7 \%$ であり, 高橋ら ${ }^{10)}$ の $76 \%$, 吉田ら ${ }^{9}$ の $77 \%$ とほぼ同等であった。一方では，もっと良い 5 年生存 率を報告している場合もあるが，統計の対象とした時 期，すなわち CDDP の出現以降の時期を中心とした集 計と考兄られる。同様にセミノーマ, NSGCT の 5 年 生存率は $90.3 \%, 75.8 \%$ で若干セミノーマが良いよ5 であるが，統計的有意差はない，諸家の報告910114)でも セミノーマが80 88\%であるのに対し，NSGCT は 60 82\%と, ややセミノーマが良い傾向にあるものの, 有意差はないとしている。

次にセミノーマの臨床病期別の生存率であるが, Stage IIa は 1 例と少なく, この Stage IIa を除く有意 差検定では, Stage I は Stage IIb およびIIIに対し, 危 険率 $0.1 \%$ で予後は良好であった。諸家の報告911014) に よる， 5 年生存率でみると, Stage Iは一般に 91.7 100\%と非常に良く, Stage II では40～60\%と生 存率は低下し, Stage III になると0〜50\%とばらつき はあるものの，かなり悲惨な結果となる，当科の成績 もほほぼ同様の傾向を示した。

NSGCT でも, セミノーマと同様, Stage I の予後は 良い。諸家の報告による Stage II の 5 年生存率は 33〜66\%であり, Stage III は0〜53\%とされており, バラッキが多いが，30 40\%程度とする傾向が多 (13)14). 5 年生存率では NSGCT の方が悪いようであ るが, 全期間通じての生存率の差は認めないとされて おり, 我々の結果も同様であった。

一般にセミノーマの Stage I 症例には高位除辠術と 予防的放射線照射を行らことで, ほぼ100\%近くの生存 率を $3 \sim 10$ 年間得られるとされている。一部には，放 射線治療の副作用である胃潰瘍や不妊症などの問題, また再発率が $10 \%$ 程度と低く，万が一，再発したとし ても化学療法等にて治癒可能である事より, surveillance policyすなわち予防的放射線治療は必要 ないとする考觉むある15).すなわち, 再発が $10 \%$ しか られないと言う事は，七ミノーマStage I の実に $90 \%$ の症例に不必要な放射線照射をしている事となる。し かし，たとえ不心要な放射線治療を行ったとしても， 長期間にわたる再発予防のための CT 検査などの煩雑 さを考えると, surveillance policy は時期尚早といら 意見もある6).
NSGCT の Stage Iに関しては, 転移がないと診断 を下した症例に対しては，不要な治療はすべきではな いという理論 ${ }^{16)}$ ，いわゆる surveillance policy(watch and see policy)が主体を占めている. たとえ, 再発し ても, 腫場マーカーの上昇で $66.7 \%$ は再発のチェック が出来，さらにェコーやCT も合わせると，60～80\% の診断率に及び，再発の発見は比較的容易であると言 $5^{16)}$.さらに再発率が $16 \sim 27 \%$ と比較的少ない上に,た とえ再発しても化学療法が有効であるので治癒率も高 いとされている17).しかし, 少なくとも高い再発率を認 める $\mathrm{T}_{3}, \mathrm{~T}_{4}$ の症例や, 原発巣における腫瘍細胞の血管 およびリンパ管への浸潤を認める症例などの危険因子 を含むものに対しては，何らかの補助療法を行った方 が良いと考学られる。我々は比較的予後が良い奇形腫 や卵黄囊腫に関しては watch and see policyでのぞ み, 結果としては全例が生存していた。しかし，他の 症例では，ほとんどが化学療法を追加した。今後は, 他の組織型でも，NSGCT の Stage I で危険因子の無 い症例には watch and see policy で望みたいと考兄て いる.

今回, 我々の症例では Stage IIa の症例が少なく, 結 論めいた事は言光ないが，一般的には Stage IIaの予 後は良好とされ，七ミノ一マでは高位除辠術に放射線 治療を行うのみで良いとされている. NSGCT の Stage IIa に対しては, (1) RPLNDのみ, (2) RPLNDに 補助化学療法を追加, (3)化学療法のみとい53 つの考 えがあり結論は出ていない6).

一方, Stage IIb はセミノーマ, NSGCT ともに予後 が Stage IIa に比べ，大きく不良であるとされ，七ミ ノーマ, NSGCT にかかわらず化学療法が追加されな ければならない。よって, Stage IIbは Stage III と同 様な治療方針でのぞむべきとされている。

次に一般的に, 辠丸腫瘍の予後を規定する因子とし てょく言われている主訴発現から初診までの期間, 術 前血清 AFP 値, 術前血清 LDH 值, 術前血清 HCG 值, 術前血清 $\beta$-HCG 值による生存率の差を検討した。 セ ミノーマでは統計的差は認められなかったが, NSGCT では血清 LDH 值と血清 HCG 值に, 統計的 有意差を認めた。主訴発現から初診までの期間と予後 の関係では 1 カ月までと $1 \sim 3$ カ月までの間に差を認 めたとする報告18)や， 3 カ月を境に予後に差が出ると する報告 ${ }^{14)}$ が認められるが，我々の検討では差がな かった。 また，NSGCT で血清 AFP 值，血清 $\beta$-HCG 值による生存率に有意差を認めないのに対し, 血清 
LDH 值, 血清 HCG 值による生存率に差を認めたこと は，偶然にも阿曽ら ${ }^{14)}$ の報告と一致しており，興味深 い. 血清 HCG 值では差を認めないのに対し,より正確 な Tumor marker とされる血清 $\beta$-HCG 值で差を認 めないのは, 血清 $\beta$-HCG 值を測定出来るようになっ た時期が，CDDP 出現の時期と重なっており，血清 $\beta$-HCG 值が高く予後不良と考えられる症例も, CDDP を中心とした有効な化学療法のため, 予後改善が得ら れた可能性があると考兄られた。

次に, 化学療法の効果をみるため, Stage IIb 以上の 進行殬丸腫瘍 (GCT のみ) に対して，CDDP を含む化 学療法を行った群と, そらでない群との生存率の差を みたが, CDDP 群の方が，有意に生存率が良かった。 松山ら ${ }^{18)}$ も PVB 扣よびVAB-6施行群とその他のレ ジメ群では危険率 $1 \%$ で有意差を認めたとしている. 我々の症例では，GCTをセミノーマおよびNSGCT に分けた検討では有意差は出なかったが，これは症例 数の少なさによるものと考光られる。

我々は，現在のところ，PVBあるいはVAB-6を Stage IIb 以上の化学療法の first line と考えている. この寛解導入化学療法による初期治療で，CR が得ら れない場合に使われるVP-16やVM-26による Salvage therapy に対する評価（遠隔成績）は，我々は症 例数も少なく行えなかった. しかし，一般にはその CR 率は40\%前後とされている ${ }^{19)}$.VP-16やVM-26と CDDP の併用による salvage therapy は，現在のとこ ろ最も良いと考学られるが，CR 率が40\%しかないと ころから，さらに良い regimen が望まれると考えられ る.

\section{結 語}

今回我々は, 久留米大学医学部泌尿器科学教室で, 1972年 4 月以降1990年10月までに経験した, 殬丸腫瘍 78例の臨床的検討を行った。年跴ではセミノーマが平 均37.5歳, NSGCT は平均 24.5 歳で, セミノーマが高 かった $(\mathrm{p}<0.01)$ ．患側は，右42例 $(53.9 \%)$, 左33例 (42.3\%) で，両側 3 例（3.9\%）であった。

病理組織学分類では，セミノーマが34例 (43.6\%) と最も多く, 奇形癌16例(20.5\%), 奇形腫 6 例 (7.7\%) の順であった。 全症例の 5 年生存率は $76.7 \%$ で, 七ミ

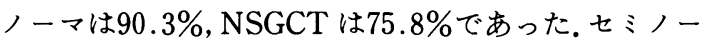
マの臨床病期別生存率では, Stage I は Stage IIb 及び IIIに対し, 予後がよく $(\mathrm{p}<0.001)$, また NSGCT でも Stage I は Stage III に対し予後が良かった（p< 0.001). 予後に与兄る背景因子に関し, 主訴発現より
初診までの期間, 術前の血清 AFP 值, 血清 LDH 値, 血清 HCG 值, 血清 $\beta$-HCG 値と血沈を検討した. セミ ノーマにはこれら因子による統計的有意差を認めな かったが，NSGCT の血清 LDH 值と血清 HCG 值は 統計的有意差を認めた. CDDP を含む化学療法の予後 に与える影響について, Stage IIb 以上の進行辠丸腫瘍 (GCT のみ) の検討では, 危険率 $1 \%$ で CDDP 群の生 存率が良かった。

\section{文献}

1) Einhorn, L.H. and Donohue, J.P.: Cisdiammine-dichloroplatinum, vinblastine and bleomycin combination chemotherapy in disseminated testicular chemotherapy in disseminated testicular cancer. Ann. Intern. Med., 87, 293-298, 1977.

2) Wittes, R.E., Yagodo, A., Silray, O., Magill, G. B., Whitmore, W., Krakoff, I.H. and Golbey, R. B. : Chemotherapy of germ cell tumors of the testis. I. Induction of remissions with vinblastine, actinomycin D and bleomycin. Cancer, 37, 637-645, 1976.

3) Cheng, E., Critkovic, E., Wittes, R.E. and Golbey, R.B.: Germ cell tumors (II) VAB-II in metastatic testicular cancer. Cancer, 42, 2162-2168, 1978.

4）三木恒治, 古武敏彦：睪丸腫煌の補助療法. 臨泌, 44, 99-115, 1990.

5) 日本泌尿器科学会, 日本病理学会編：泌尿器科. 病 理辠丸腫湯取扱い規約，第 1 版，p. 4-135，金原 出版, 東京, 1984.

6) Vurqrin, D., Herr, H.W. and Whitomore, W.F.: VAB-6 combination chemotherapy in disseminated cancer of the testis. Ann. Inter. Med., 95, 59-61, 1981.

7）山下修史，金武 洋，斉藤 泰，小浜常昭，吉本 純, 井川幹夫, 松山豪泰, 滝川 浩, 内藤誠二, 木 宮公一, 松岡 啓, 早川正道：難治性辠丸腫湯の Salvage 療法の現況。西日泌尿，51，436-439， 1989.

8）大野良之，青木国雄，黒石哲生，富永祐民：日本人 の尿路性器癌の疫学、臨泌，38，555-569, 1984.

9）吉田一成, 川上達史, 野村一雄, 西村清志, 吳 幹 純, 高木 裕, 入江 啓, 村山雅一, 岩村正嗣, 泉 博一, 小田島邦雄, 内村豊昭, 石橋 晃, 小柴 健: 鼻丸腫場の臨床統計．泌尿紀要，33，1396-1403， 1987.

10）高橋徳男, 大矢 晃, 網野洋一郎, 染野 敬：辠丸 腫場 38 例の臨床的検討. 西日泌尿, 51，803-807, 1990.

11）熟塚 誠：睪丸腫煬725例の症例集計. 河合恒雄, 
町田豊平 編, 睾丸腫瘍の診断と治療, 第 1 版, p. 99 -114 , 篠原出版, 東京, 1986 。

12）入澤千晶，柿崎 弘，金子尚嗣，平野順治，石井延 久, 沼沢和夫：両側精細胞性鼻丸腫場の 1 例. 泌尿 紀要， 35，1795-1800， 1989.

13）野俣浩一郎，西村直樹，谷口啓輔，金武 洋，進藤 和彦, 斉藤 泰, 島田 修, 津田暢夫, 田崎 享, 原 種利, 高野真彦, 佰本 滋, 草場泰之, 計屋紘 信, 岩崎昌太郎：辠丸腫瘍の臨床統計的研究。癌の 臨床, 34, 1115-1120, 1988.

14）阿曾佳郎, 鈴木和雄, 須床 洋, 中原正男, 鈴木明 彦, 増田宏昭, 牛山和己, 畑 昌宏, 太田信隆, 大 見嘉郎, 太田原佳久, 田島 憞：浜松医科大学泌尿 器科教室開講後 10 年における鼻丸腫瘍の治療成 績。日泌尿会誌，79，1248-1253，1988。

15) Thomas, G.M., Sturgeon, J.F., Alison, R., Jewett, M., Goldberg, S., Sugar, L., Rideout, D., Gospodarowicz, M.K. and Duncan, W.: A study of post-orchiectomy surveillance in stage I testicular seminoma. J. Urol., 142, 313-316,
1989.

16) Peckham, M.J., Barrett, A. and Husband, J.E.: Orchiectomy alone in testicular Stage I nonseminomatous germ cell tumors. Lancet, 11, 678-680, 1982.

17）山口豊明，小川勝明，古畑哲彦，植草富二郎： Watch and see policy にて再発し，治撚できた辠 丸非セミノーマの 1 例。医療, 12, 1172-1175, 1988.

18）松山豪泰，山本憲男，酒徳治三郎，林田重昭，佐長 俊昭, 原 好弘, 永田一夫, 越戸克和, 林 淳二, 原田宏行, 藤澤章二：転移を有する殬丸腫場の治 療成績。西日泌尿，51，428-435，1989.

19）三木恒治，友岡義夫，吉村一宏，前田修，細木 茂, 木内利明, 黒田昌男, 清原久和, 宇佐美道之, 古武敏彦：難治性辠丸腫瘍に対する VM-26, VP16 を用いた Salvage 化学療法の治療成績。日泌尿 会誌，80，1609-1616，1989.

（1991年 5 月 2 日受理） 